\title{
高温超電導テープ線材の局所 $J_{\mathrm{c}}$ 分布評価技術
}

\author{
木須 隆暢
}

\section{Characterization Techniques for Local Critical Current Densities in HTS Tapes}

\author{
Takanobu KISS*
}

\begin{abstract}
Synopsis: The high spatial homogeneity of critical current density, $J_{\mathrm{c}}$, in HTS tape is one of the most important requirements to realize practical superconducting tapes. However, it is hardly possible to detect local $J_{\mathrm{c}}$ distribution using conventional characterization techniques because the length scale of such $J_{\mathrm{c}}$ variation is several orders smaller than that of the conventional techniques. We have succeeded in developing novel techniques such as low-temperature laser scanning microscopy and reel-toreel Hall probe scanning microscopy for spatially resolved measurements of local $J_{\mathrm{c}}$ in HTS tapes of multiple lengths and operating conditions. In this paper, I summarize these techniques together with other useful methods including magneto-optical imaging and the Hall sensor array technique.
\end{abstract}

Keywords: high $T_{\mathrm{c}}$ superconducting tape, critical current, spatial distribution, low temperature laser scanning microscopy, magnetic microscopy

\section{1. はじめに}

高温超電導線材の臨界電流密度は、一般に四端子法や磁 化法によって評価される。四端子法においては、試料両端 より電流 $I$ を印加し、電圧端子間に誘起される電界あるい は抵抗率が基準值に達したところで臨界電流值 $I_{\mathrm{c}}$ を定義 する。ここで、電界は発生電圧 $V$ を電圧端子間距離で除 した值で定義され、臨界電流密度 $J_{\mathrm{c}}$ は試料の超電導断面 の面積で $I_{\mathrm{c}}$ を除した值として定義される。超電導線材は 一次元の電流輸送媒体であることを考えると、四端子法は 最も実用環境に近い状態での測定であり、その意味で測定 法としての重要性も高い。また、磁化法においては試料全 体の磁気モーメントを測定し、臨界状態モデルによる磁化 電流の空間パターンを仮定し、試料内の磁化電流密度を評 価する。臨界状態モデルによると、試料内の磁化電流密度 の大きさは $J_{\mathrm{c}}$ と等しく 1 、よって試料の $J_{\mathrm{c}}$ 值の評価が可 能となる。磁化法では電流電圧端子の取り付けも必要な く、かつ大電流印加時の試料の焼損といった問題も回避で きる利点を有する。しかしながら、いずれの手法も直接の 観測量は試料サイズに亘るマクロな物理量であり、 $J_{\mathrm{c}}$ の值 は試料の均一性を前提として導出されている点に注意が必

\footnotetext{
Received September 4, 2014

* 九州大学大学院システム情報科学研究院

干819-0395 福岡県福岡市西区元岡 744

Department of Electrical Engineering, Kyushu University,

744 Motooka, Nishi-ku, Fukuoka 819-0395, Japan

E-mail: kiss@sc.kyushu-u.ac.jp

DOI : $10.2221 /$ jcsj. 49.465
}

要である。筆者らは研究の初期の段階から、高温超電導線 材の電流輸送性能は、局所不均一性の影響を顕著に受ける ことを指摘し ${ }^{2,3)}$ 、試料内の局所的な $J_{\mathrm{c}}$ 分布の評価が本質 的に重要であることを示してきた。超電導体特有の非線形 な電界一電流密度 $(E-J)$ 特性のため、欠陥近傍の僅かな 電流不均一は電界の著しい空間局在を引き起こす ${ }^{4,5)}$ 。こ のことから、線材内の空間均一性は、臨界電流の向上や信 頼性の確立など、実用上重要な研究課題である。電流制限 因子の解明のためには、SEM や TEM を用いた $\mathrm{nm}$ から $\mu \mathrm{m}$ スケールの結晶組織観察が極めて有効であるが、その 観測領域は典型的に数 $10 \mu \mathrm{m}$ から $100 \mu \mathrm{m}$ 程度に制限され る。よって、筆者らは、臨界電流制限因子を明確化し高性 能線材を実現するアプローチとして、電磁気的な顕微手法 を用いて局所的な $J_{\mathrm{c}}$ 分布を数 $10 \mu \mathrm{m}$ から $100 \mu \mathrm{m}$ の解像度 で明らかとし、 $J_{\mathrm{c}}$ 低下位置を特定した上で SEM や TEM との複合観察を行うハイブリッド顕微法を提案している。 さらに、工業材料としての実用線材は $\mathrm{km}$ オーダーである ことから、品質管理の視点からは、長尺線材の高速な評価 が求められる。また、一連の高温超電導線材は、幅広の テープ形状を有していることから、線材磁化の大きさに影 響する線材幅や、局所的な $J_{\mathrm{c}}$ 低下部位の面内での位置検 出など、2 次元的な空間情報の取得が重要であることを指 摘し、そのための評価手法の確立に取り組んできた。

$J_{\mathrm{c}}$ 分布の評価手法としては、電流を流した時の発生電界 を観測する手法と、試料内電流から生じる磁界を検出する 手法とに大別できる。しかしながら、観測目的に応じて対 
象とする空間スケールは何桁も変化し、また温度、磁界な どの動作環境や試料内の電流密度や電界も大きく変化する ため、観測手法も多様に変化する。本稿では、筆者等がこ れまで開発してきた、低温レーザ走査顕微鏡、走查型 SQUID 顕微鏡、走查型ホール素子顕微鏡を中心として、 磁気光学法や既に市販の評価装置が普及している配列 Hall 素子法など他の手法も含めて、高温超電導テープ線材にお ける $J_{\mathrm{c}}$ の空間分布を測定する手法について解説する。

\section{2. 短尺線材の局所 $J_{c}$ 分布評価技術}

\section{1 低温レーザ走査顕微鏡 (LTLSM)}

欠陷等の電流阻害因子が存在する場合は、超電導体特有 の非線形な通電特性のために、損失は欠陥近傍に局在す る。高温超電導体の $E-J$ 特性は $E$ が $J$ の $n$ 乗に比例して増

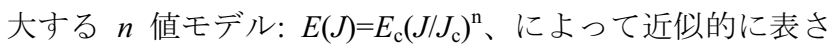
れることが知られている。ここで $E_{\mathrm{c}}$ は電界基準であり一 般に $1 \mu \mathrm{V} / \mathrm{cm}$ が用いられる。欠陥近傍では電流が迂回寸 ることにより偏りが生じ、電界はその $n$ 乗で増大寸ること から空間的な局在を生じる ${ }^{4,5}$ 。ここのことは $n$ 值が大きい ほど顕著となる。しかしながら、不均一性が問題となる典 型的な空間スケールは、数 $\mu \mathrm{m}$ から $100 \mu \mathrm{m}$ 程度であり、 一般に用いられる四端子法による空間分解能に比べ何桁も 小さい。そこで我々は、集光したレーザビームを用いて、 磁束フロー電圧の空間情報を選択的に取得する低温レーザ 走查顕微鏡法（LTLSM: Low Temperature Laser Scanning Microscopy）を用い、超電導線材内の局所的損失分布を観 測するシステムを構築した ${ }^{5-8)}$ 。

Fig. 1 に本測定法の原理と筆者らの研究室で開発した高 磁界対応の装置の外観写真を示す。本装置では、超電導状 態の試料に一定電流を印加し、強度変調を加えたレーザス ポット光を試料表面に照射し局所的に加熱することにより $J_{\mathrm{c}}$ の変調を加え、レーザ照射位置で生ずる電圧応答をロッ クインアンプを用いて計測する。対物レンズを用いてレー ザを集光し、試料表面に照射する。試料は、光学空を有す る温度可変クライオスタットに設置されており、電流電圧 端子の設置は通常の四端子法と同様である。レーザ照射に 伴い、試料内の温度が周囲の温度に比べ局所的に僅かに上 昇する。したがって、レーザ照射によって照射位置でのみ 臨界電流が局所的に低下し、その結果、熱的に磁束フロー が誘起され、端子間に電圧を生じる。すなわち、レーザ照 射時の $J_{\mathrm{c}}$ 值が、観測点のバイアス電流密度 $J$ より小さく なる点で磁束フローが誘起され、電圧応答を生じる。この ときの電圧振幅の大きさは、超電導体特有の強い非線形性 を有する $E-J$ 特性のために、局所電界に比例する。例え ば、 $E-J$ 特性が $n$ 值モデルで与えられる場合、レーザ照射 位置における出力電圧 $\Delta V$ は以下のように与えられる ${ }^{8)}$ 。

$$
\Delta V(x, y) \approx-\frac{\partial J_{c}}{\partial T} \frac{E(x, y)}{J_{c}} 2 n \Lambda \Delta T
$$
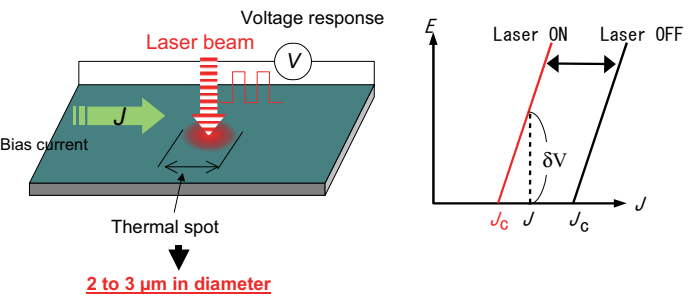

2 to $3 \mu \mathrm{m}$ in diamete

Allows us to enhance the spatial resolution

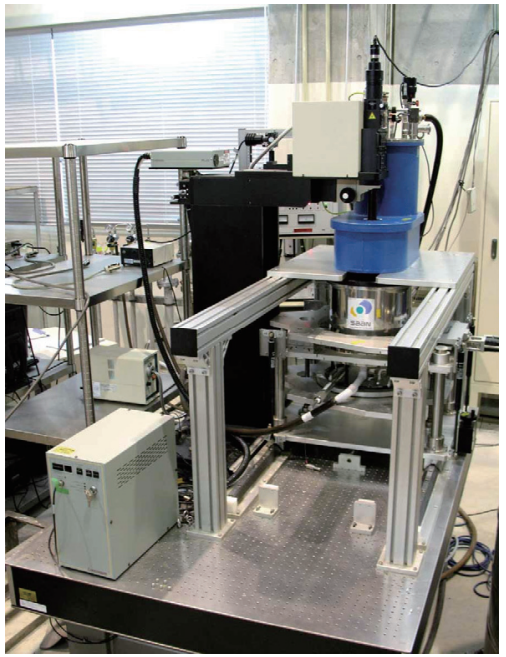

Fig. 1 Principle of low-temperature laser scanning microscopy (LTLSM), and a photograph of a high-field LTLSM (HF-LTLSM) system developed in our laboratory.

$100 \mu \mathrm{m}$

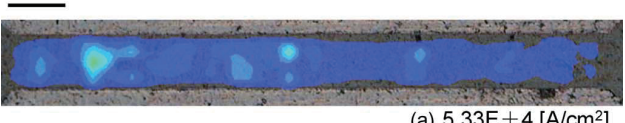

(a) $5.33 \mathrm{E}+4\left[\mathrm{~A} / \mathrm{cm}^{2}\right]$
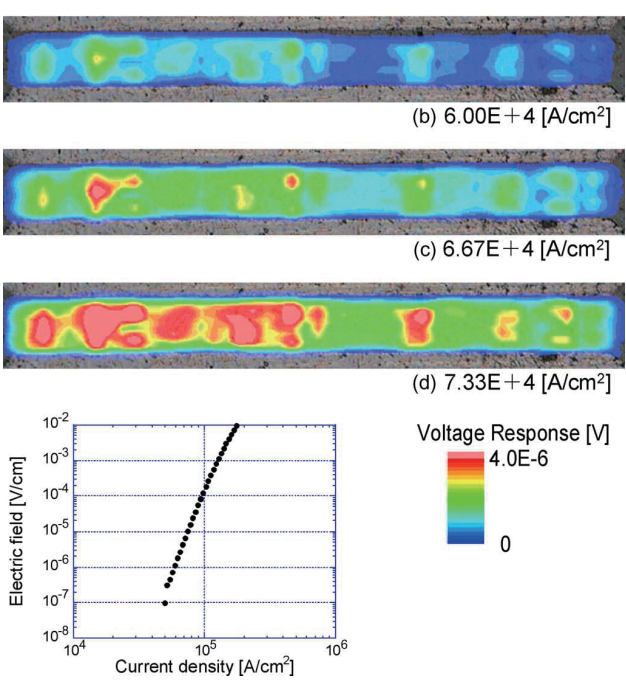

Voltage Response [V]

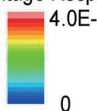

Fig. 2 Visualization of local flux flow dissipation using the HF-LTLSM under an external magnetic field of $1 \mathrm{~T}$ at 84 $\mathrm{K}$ in a $100 \mu \mathrm{m}$-wide, $1 \mathrm{~mm}$-long micro-bridge patterned in a YBCO-coated conductor. Bias current density was increased from (a) $5.33 \times 10^{4}$, (b) $6.00 \times 10^{4}$, (c) $6.67 \times 10^{4}$, and (d) $7.33 \times 10^{4} \mathrm{~A} / \mathrm{cm}^{2}$. The inset shows global $E-J$ characteristics of the bridge obtained using the conventional four-probe method. 
ここで、 $\Lambda$ はレーザスポットの半径、 $\Delta T$ はレーザ照射に 伴う局所的な温度上昇を示す。

レーザスポットの照射位置を試料面内で走査することに より、試料面内の電界分布を得ることが可能となる。レー ザのスポット径は 2 3 $\mu \mathrm{m}$ であり、典型的に数 $\mu \mathrm{m}$ の空間 分解能で損失分布の観測が可能となる。すなわち、従来の 四端子法に比べ、空間分解能を飛躍的に向上させることに 成功した。したがって局所的な電界基準によって $J_{\mathrm{c}}$ の空 間分布を評価できる ${ }^{6,7)}$ 。本手法はまた、高磁界中でも適 用可能であるという大きな利点を有している。本システム では、試料ステージ部位を室温ボアを有する超電導マグ ネット内に配置しており、試料面に対して垂直方向に最大 $5 \mathrm{~T}$ の磁界を印加することが可能である。

Fig. 2 に Ion Beam Assisted Deposition（IBAD）法で製作 した配向基材上に成膜した YBCO コート線材を用いて、1 $\mathrm{T}$ の外部磁界中で、磁束フロー損失の空間分布を可視化し た例を示す。印加電流の増大に伴って、局所的に $J_{\mathrm{c}}$ が低 い領域から損失が発生していることが分かる。本試料は、

$77 \mathrm{~K}$ 、自己磁界中で $2 \mathrm{MA} / \mathrm{cm}^{2}$ 程度の $J_{\mathrm{c}}$ 值を有するが、 $J_{\mathrm{c}}$ 向上のためには均一性のさらなる向上が有効であることを 示している。低 $J_{\mathrm{c}}$ 領域は、数 $10 \mu \mathrm{m}$ 数 $100 \mu \mathrm{m}$ 程度の間 隔で現れており、IBAD や YBCO 層のグレインサイズに比 ベて遙かに大きい。

\section{2 走査型 SQUID 磁気顕微鏡 (SSM)}

前節に述べた、試料内の局所電界と相補的な物理量とし て、局所電流密度がある。局所的な電流分布を計測する手 法としては、試料近傍の磁界分布を計測する磁気顕微法が ある。用いる磁気センサによっていくつかの手法に分類さ れ、その特徵も異なる。本節では、高感度な磁気計測を可 能とする SQUID 磁気センサを用いた、走査型 SQUID 磁 気顕微鏡（SSM: Scanning SQUID Microscope）による電流 分布の評価法について述べる。

本測定では、金属系 SQUID を用い、センサチップ上に 直径 $10 \mu \mathrm{m}$ の 1 ターンコイルからなるピックアップコイ ルと SQUID 素子を集積し、試料表面を走査することに よって垂直磁界成分の 2 次元磁気像を得る。走査の際の 試料表面とピックアップコイルとの距離は典型的には 数 $\mu \mathrm{m} \sim 10 \mu \mathrm{m}$ の条件で測定を行う。試料は真空断熱雰囲 気に配置され、SQUID センサと試料ステージとは独立な 温度制御が可能である。

Fig. 3 に Fig. 2 に示したものと同じ試料を用いて、SSM によって得られた自己磁界分布の通電電流依存性の測定結 果を示す ${ }^{8)}$ 。自己磁界分布が通電電流の複雑な流れを反映 して不均一になっていることが分かる。また、試料端から 侵入する磁界が、電流の増大に伴いパーコレーション的に 広がっている様子が確認できる。

磁気像より、ビオ・サバール則の逆問題を解くことによ り、各座標位置でのシート電流ベクトルを求める ${ }^{9)}$ 。逆問

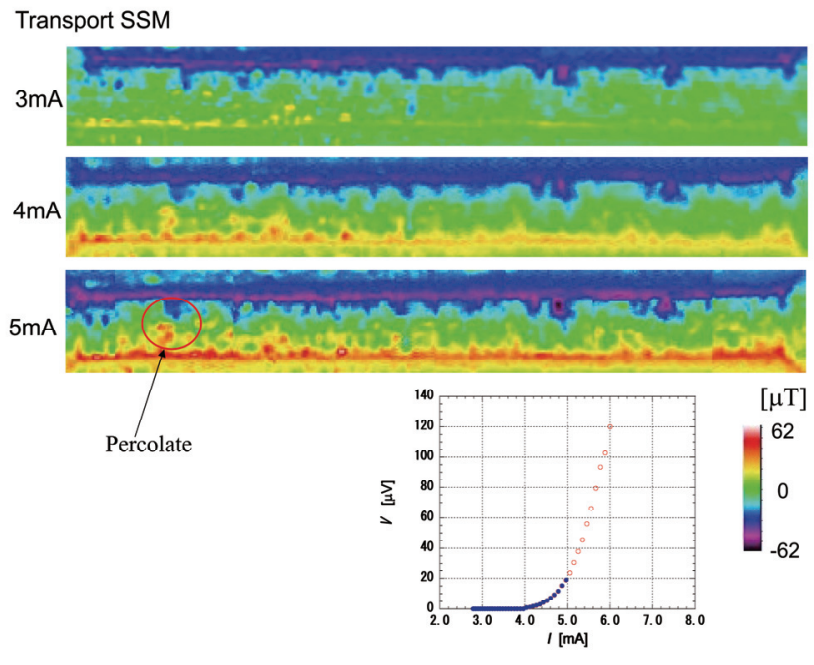

Fig. 3 Self-field distribution observed using a scanning SQUID microscope (SSM) with transport currents: 3, 4, and $5 \mathrm{~mA}$ at $87.4 \mathrm{~K}$. The inset shows the global $I-V$ characteristics of the bridge. The sample is the same as that shown in Fig. 2.

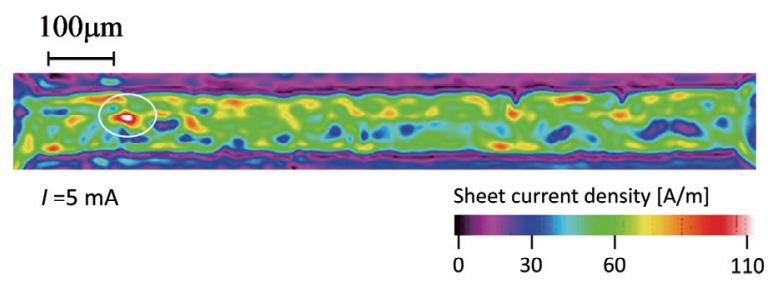

Fig. 4 Sheet current density distribution obtained from the self-field image shown in Fig. $3(I=5 \mathrm{~mA})$ by solving the inversion problem of the Biot-Savart law. Thickness of the YBCO layer is $300 \mathrm{~nm}$.

題による $J_{\mathrm{c}}$ 分布の導出において、試料の厚さ方向の電流 分布がある場合には一意の解を得ることが困難であるが、 厚さ方向の分布を無視し、表面のみに流れるシート電流と して近似できる場合には、磁気像より電流ベクトル分布の 導出が可能である。また、膜厚方向の分布を一定と仮定す ると、シート電流密度を膜厚で除することで単位断面積当 たりの電流密度を得ることができる。HTS テープ線材に おいて超電導層の厚さは十分薄く、シート電流の近似は良 く成り立つ。逆問題の解析手法は種々の方法が提出されて いるが、本研究では、離散フーリエ変換を用い、波数空間 で解く手法を採用している ${ }^{9,10)}$ 。

Fig. 3 に示した自己磁界分布から求めた電流分布を Fig. 4 に示す。線材内部において通電電流が不均一に分布する様 子が分かる。同図中に円で示した領域は、Fig. 3 の $5 \mathrm{~mA}$ 通 電時の自己磁界分布に示すように、ブリッジの臨界電流に 到達した際に磁束がパーコレートする領域に対応している。 この部位の局所的電流密度の最大值は、均一に流れた際の 平均の電流密度に比べ 2 倍程度に増大している。その結果、 Fig. 2 に示したようにこの部位において局所電界が発生し 

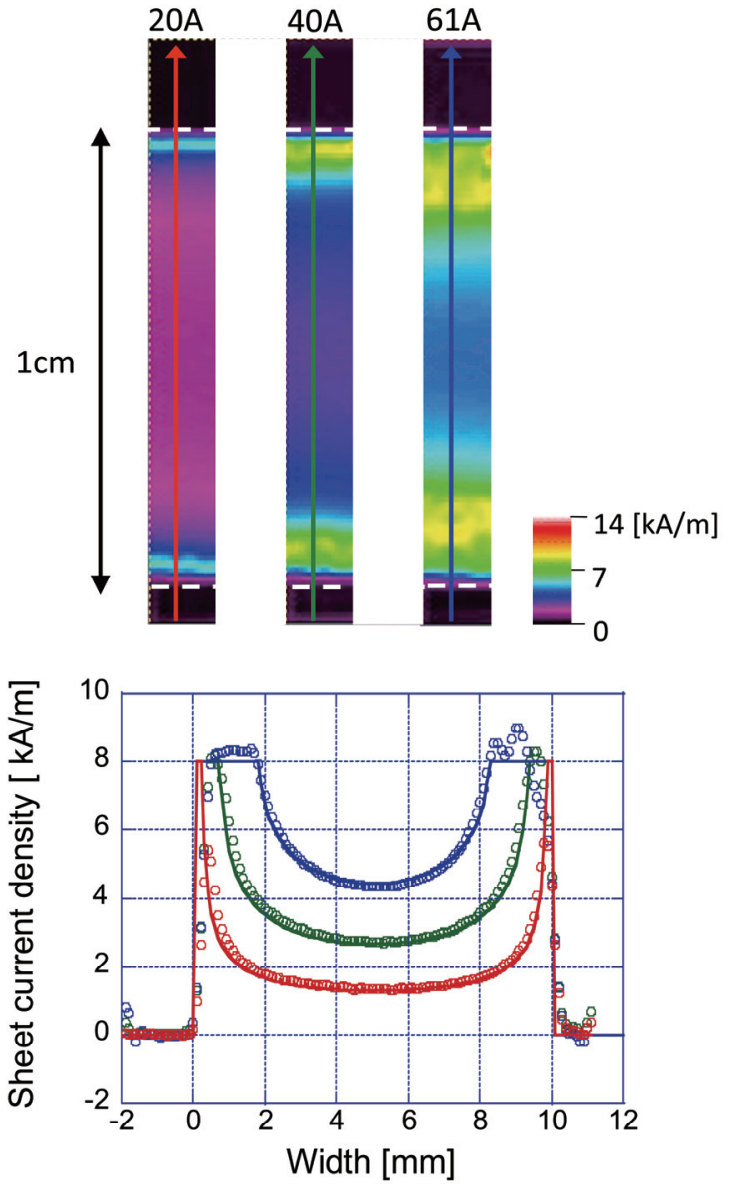

Fig. 5 Sheet current density distribution obtained using a scanning Hall probe microscope (SHPM) for a $1 \mathrm{~cm}$-wide YBCO-coated conductor tape with different values of bias current: 20, 40, and $61 \mathrm{~A}$. The lower panel shows transverse distribution at the position shown by the arrow in the upper panel. The solid lines are theoretical calculations using the critical state model $^{1)}$.

ている。同図 (c) が通電電流がブリッジの $I_{\mathrm{c}}$ にほぼ到達し た時の局所電界分布を示している。両端で観測される電圧 は、磁束分布がパーコレートした領域が集中的に担ってお り、他の部位はまだ磁束フロー状態に達していないことが 分かる。すなわち、パーコレートした部位がボトルネック となり、マクロスケールで観測される $I_{\mathrm{c}}$ が制限されている ことを示している。

\section{3 走査型 Hall 素子磁気顕微鏡 (SHPM)}

SQUID センサは高感度である一方、飽和磁界による制 限から線材に対して大電流印加時あるいは高磁界中の評価 を行うには、磁気センサとして Hall 素子が適している。 本節では、走査型ホール素子顕微鏡（SHPM：Scanning Hall-Probe Microscope）の基本原理と計測例について 紹介寸る。なお、詳細については本特集号の東川ら によるテーマ解説の頁 ${ }^{11)}$ を参照されたい。

SHPM の測定原理は基本的にはSSM と同様であ る。測定モードとしては、通電電流を印加し、自己
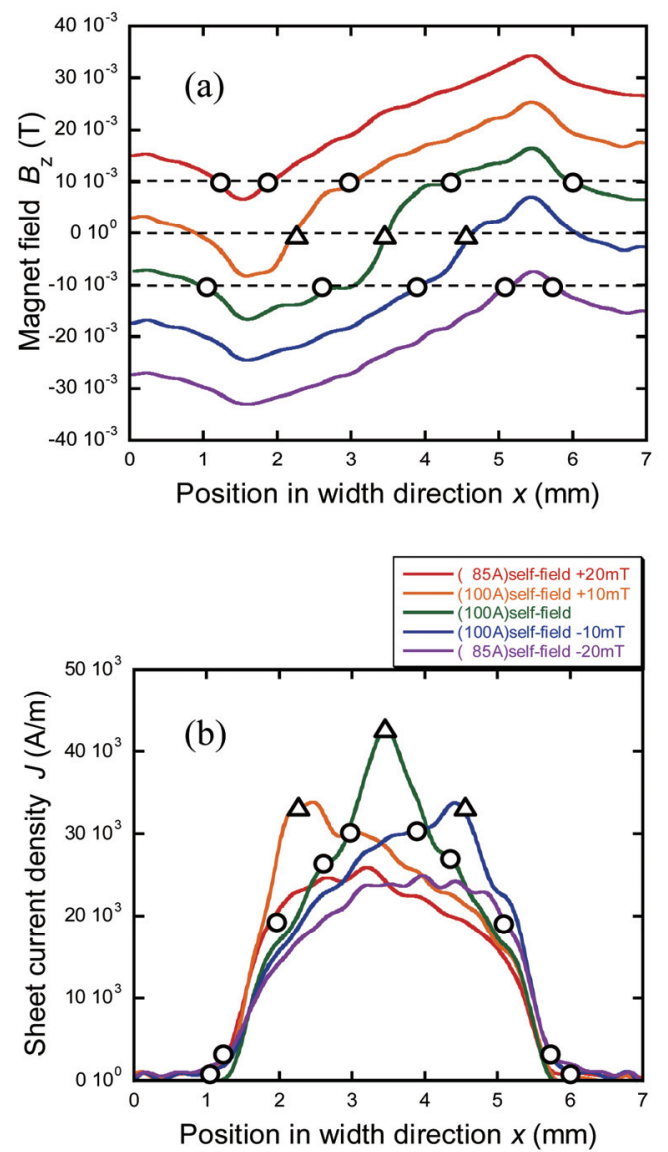

Fig. 6 Transport SHPM image of a Bi-2223 multi-filament tape. Transverse distribution of the (a) perpendicular component of the magnetic field, and (b) sheet current density with bias currents close to $I_{\mathrm{c}}$ under different values of external magnetic fields applied perpendicular to the tape surface from -20 to $20 \mathrm{mT}$ at $87 \mathrm{~K}$.

磁界分布を計測するモードと、外部磁界の印加に よって線材を磁化し、その磁束分布より面内の磁化 電流を評価する測定モードとに分けられる。後者 は、試料への端子を必要とせず、非接触な測定が可 能であることから、後述する長尺線材の高速測定に 適している。

いずれの測定モードにおいても、SHPM で試料表面 の磁界分布を測定し、ビオ・サバール則の逆問題を解くこ とによって試料面内の電流分布を得る。筆者らの開発した 装置では、感受領域 $50 \mu \mathrm{m}$ 角の微小ホール素子を走査ス テージにマウントし、試料表面から一定距離の磁気像を取 得している。幅 $1 \mathrm{~cm}$ のコート線材に電流を流した際の評 価例を Fig. 5 に示す。試料端部より徐々に電流が侵入する

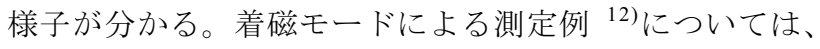
東川らの頁を参照されたい。

本手法はまた、コート線材のみならず、Bi-2223 多芯線 材への適用も可能である $\left.{ }^{13}, 14\right)$ 。Fig. 6 に外部磁界下で臨 


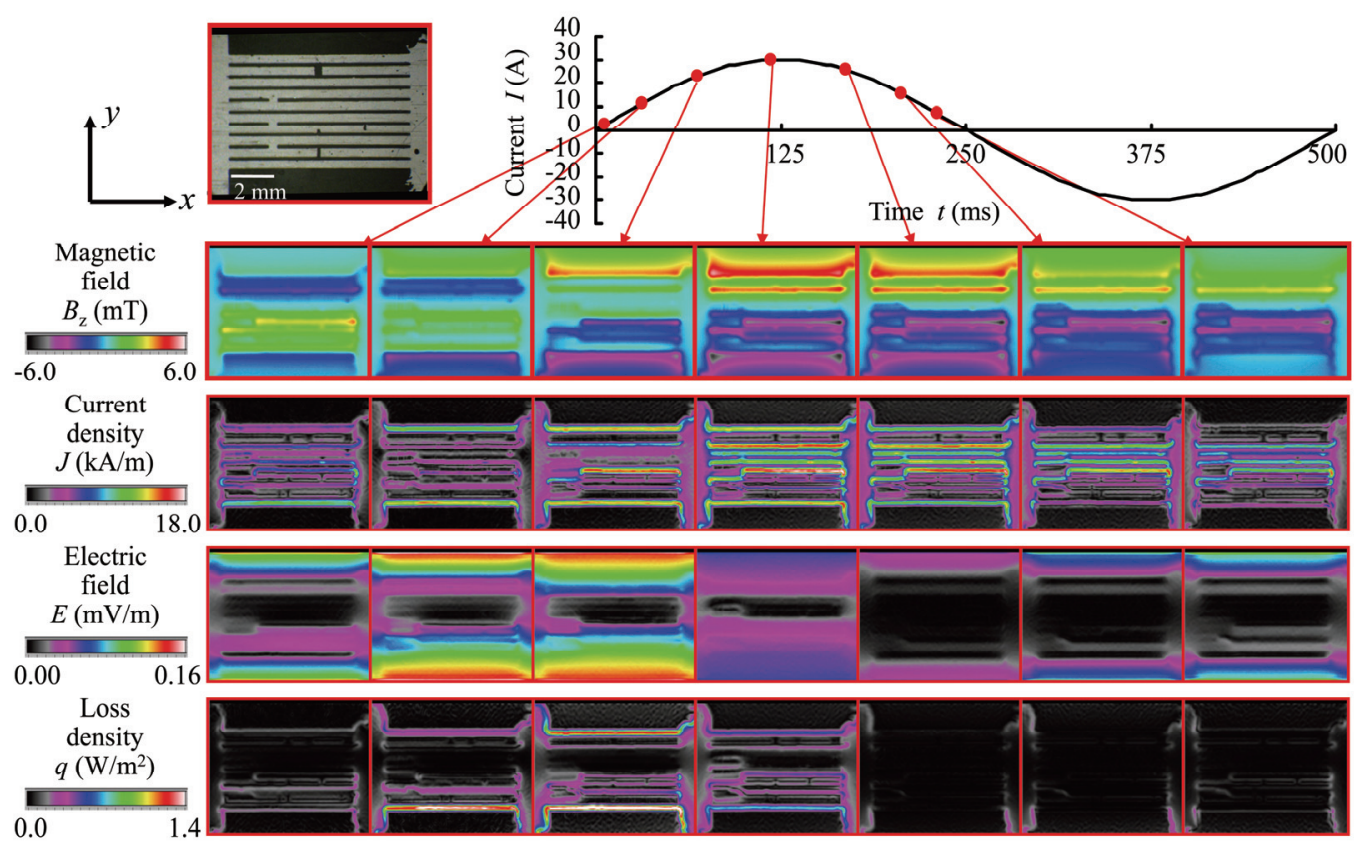

Fig. 7 Spatially resolved measurement of timedependent electromagnetic field distribution using a transport SHPM with an alternating bias current. ${ }^{15)}$ The multi-filament model sample was formed in a YBCOcoated conductor.
界電流を印加した際の Bi-2223 線材の観測例を示す。素線 内の電流分布は幅方向に大きな分布を有しており、これは フィラメント領域の分布と自己磁界分布の影響によって説 明できる。また、このような素線内の電流輸送特性の分布 は、集合導体化した際の電流容量に大きな影響を及ぼし、 導体設計の基本となる情報である ${ }^{14)}$ 。

また、周期的な電流を印加寸る場合は、各座標位置にお いて位相遅れを調整しながら同期した磁気像を取得するこ とにより、一周期分の時間依存性を含めたデータを取得す ることが可能となる。模擬的なマルチフィラメント線に対 して $2 \mathrm{~Hz}$ の交流電流を印加しつつ、磁気像の時間依存性 を取得し、ビオ・サバール則の逆問題より電流分布を、ま たファラデー則より電界分布を評価した結果を Fig. 7 に示 す。さらに、電流密度と電界との積により、交流損失の瞬 時值の空間分布の像とその時間発展を得ることが可能とな る 15)。電流は試料端部より位相遅れを伴って試料内部に 侵入し、また損失は試料端部に集中している様子が分か る。これらの振る舞いは、本試料では両端の電極部分で フィラメントが結合していることから理解できる。また、 局所的にフィラメントが結合している部位や、部分的に断 線している複雑な形状を有する領域における電磁現象を定 量的に把握する手法として威力を発揮する。

\section{4 磁気光学イメージング法 (MOI)}

磁気光学イメージング法 (MOI: Magneto Optical Imaging）は、磁気光学膜（インジケータフィルム）を用 いて試料表面の磁界分布を光学像として可視化する手法で ある。一般には、インジケータフィルムとして面内磁化膜 を用い、膜面に対して垂直な磁界成分によるファラデー回 転を用いて、垂直磁界分布を偏光顕微鏡像の濃淡のイメー
ジとして観測する 16-19)。磁気光学イメージングの原理図 を Fig. 8 に示す。インジケータフィルムの感度をあらかじ め校正することで、磁界分布の定量的な評価が可能とな り、したがって試料表面とインジケータフィルム間の距離 が分かれば、SHPM と同様に試料表面の電流分布を得るこ とができる 16，17)。本手法は、テープ線材との整合性に優 れており、インジケータフィルムと試料間を密着すること ができれば、1 $1 \mu \mathrm{m}$ 以下の優れた解像度を実現できる。ま た $10 \mathrm{~mm}$ 角以上の広い視野を一度に観測できるといった 優れた利点を有する。ただし、観測可能な磁界の範囲は、 インジケータフィルムの飽和磁界によって制限され、典型 的には $0.1 \mathrm{~T}$ 以下に限られる。

Fig. 9 に SHPM と MOI とを用いて、同一の試料（幅 1 $\mathrm{cm}$ のコート線材）を評価した結果を示す。特徽的な部分 における像が一致しており、両者は同等の情報を取得でき ることが分かる。両者の結果を詳細に比較すると、解像度 においては、拡大図より分かるとおり MOI の方が優れて いる。一方、MOI 観察では偏光顕微鏡像取得の際の露光 条件によっても像の濃淡が変化しており、磁界強度に変換 する際には、露光条件も考慮した面内での変換係数の分布 を考慮する必要があり、特に大面積での測定の際には、注 意が必要である。

\section{5 誘導法}

励磁コイルを用いて超電導テープ面に垂直に正弦波形の 交流磁界を印加し、超電導層に誘起された誘導電流が作る 磁界を検出コイルで検知する手法である 20-22)。誘導電流 が臨界電流值以下の場合、誘導電流によって生じる磁界も 正弦波となるが、励磁コイルの磁界振幅の増大によって誘 導電流の大きさが臨界電流值に到達すると、誘導による磁 
界波形は、最大振幅が飽和した波形へと変化する。よっ て、この時検出コイルで観測される周波数成分には奇数次 の高調波が生じるため、検出コイルに高調波成分が生じる ときの励磁電流によって、直下の膜の臨界電流值を計測す ることができる。測定には、一般には 3 倍高調波が用いら れる。また、励磁コイルの周波数によって膜中に誘起され る誘導電界を変化させることができるため、異なる励磁周 波数による測定から、臨界電流の電界依存性の評価が可能

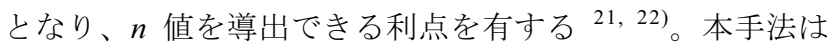
非接触・非破壊な測定が可能な点で、他の磁気的手法と同 様の特徵を有する。ただし、空間分解能は励磁コイルのサ イズと同程度であり、観測領域内に不均一性が存在する場 合、その測定結果の解釈には注意が必要である。また、本 手法は元々大面積薄膜の $I_{\mathrm{c}}$ 分布評価手法として提案され たものであるが、近年のコート線材は膜厚の増大に伴って $I_{\mathrm{c}}$ 值が増大しており、励磁コイルへの大電流の印加による 発熱などの問題も考慮する必要がある。

\section{6 その他}

誌面の都合上詳細は割愛するが、その他の手法として、 永久磁石の直下に微小 Hall 素子を配置し、試料直上を走 査することによって試料からの応答磁界を計測し、面内の 磁化電流の分布を検出する手法: Magnetoscan が提案され ている 23, 24)。本手法は元々超電導バルク材の不均一性を

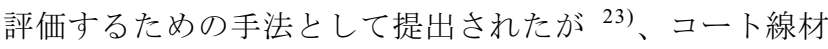
の長手方向の $I_{\mathrm{c}}$ 分布の評価にも適用可能であることが示 されている ${ }^{24)}$ 。原理的には $\operatorname{Tapestar}^{\mathrm{TM}}$ (3.2 節参照) や走 査型 Hall 素子顕微鏡と類似している。また、着磁した線 材から受ける磁気力が線材の磁気モーメントの大きさ、す なわち磁化電流の大きさに比例することを用いて、磁気力 の分布から $I_{\mathrm{c}}$ 分布を評価しようとする手法も提案されて いる ${ }^{25)}$ 。

\section{3. 長尺線材の $J_{c}$ 分布評価技術}

\section{1 リール式四端子法（尺取り法）}

液体窒素中に浸漬冷却した線材に対し、可動式の電流端 子並びに電圧端子を圧着させ、四端子法により各区間の $I-$ $V$ 特性を測定し、リールによって尺取り式に線材を搬送し ながら全長に亘って測定する評価手法である。各測定区間 は典型的に $50 \mathrm{~cm} \sim 5 \mathrm{~m}$ 程度で行われている ${ }^{26-28)}$ 。本手法 は、通電時の発生電圧を観測するという点で、実際に線材 が使用される環境での評価に最も近い。また、I $I_{\mathrm{c}}$ 值のみな らず $n$ 值の評価が可能であり、線材の実用パラメータの取 得に適している。最近では、磁界発生コイルと組み合わせ て磁界下の $I_{\mathrm{c}}$ 值や $I_{\mathrm{c}}$ の磁界印加角度依存性の長手分布の 評価が可能な装置が開発されている ${ }^{29,30) 。 ~}$

ただし、高 $I_{\mathrm{c}}$ 線材になると電流端子接触部での発熱が 無視できない点や、各区間での $I-V$ 特性の測定が必要のた め高速化には限界があること、また、空間分解能が電圧端

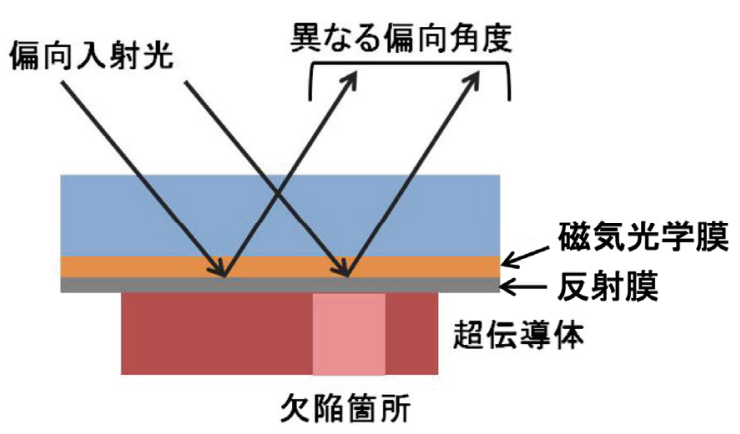

Fig. 8 Principle of the magneto-optical imaging (MOI).

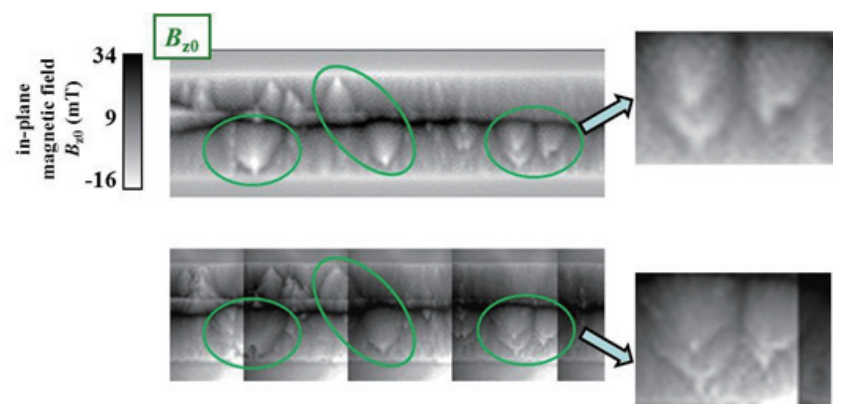

Fig. 9 Comparison between SHPM (upper) and MOI (lower) obtained from the same $1 \mathrm{~cm}$-wide coated conductor.

子間距離で制限されることから、局所的な $I_{\mathrm{c}}$ 低下の検出 が困難であるという問題も指摘されている ${ }^{31) 。 ~}$

\section{2 配列 Hall 素子法 (Tapestar ${ }^{\mathrm{TM}}$ )}

線材に垂直磁界を印加した際の幅方向の侵入磁界の分布 を線材直上に配置した配列 Hall 素子によって計測し、そ の磁界分布より直下（座標位置 $x$ ) にある線材の臨界電流 值を評価する。Fig. 10 に装置の原理図を示す。最も典型 的な装置では、等間隔に配列した 7 個のセンサによって テープ面直上の侵入磁界分布を計測し、テープ内の幅方向 の $J_{\mathrm{c}}$ 分布は均一と仮定して臨界状態モデルにより、セン サ位置に発生する磁界分布を導出し、フィッティングパラ メータとして $I_{\mathrm{c}}$ 值を決定する ${ }^{32)}$ 。センサの数を増やして、 線材の幅方向の非対称性を捉えることも可能であるが、一 般に幅方向の解像度は余り高くない。また、得られる $I_{\mathrm{c}}$ 值は線材とセンサ間の距離に依存し、また測定時の誘導電 界も四端子法の電界基準と異なっているため、通電法の $I_{\mathrm{c}}$ と比較するためには校正を行う必要がある。特に、 $n$ 值 が低い場合は、 $I_{\mathrm{c}}$ 值が小さめに見積もられる可能性があ る ${ }^{33)}$ 。長手方向の分解能は $1 \mathrm{~mm}$ 程度と高いため、 $I_{\mathrm{c}}(x)$ の測定データは短い周期で複雑に変化する。そこで、一般 には各座標位置 $x$ 近傍のある区閒長における $I_{\mathrm{c}}$ の最大值と 最小值を求め、その $x$ 依存性を示したグラフが用いられる。 Fig. 11 に $200 \mathrm{~m}$ 級の市販コート線材の測定例を示す。本 
手法は、ドイツ Theva 社より $\operatorname{Tapestar}^{\mathrm{TM}}$ として評価装置が 市販されていることもあって、前述のリール式四端子法と 共に現在最も一般的な長尺線材の評価手法として線材メー カなどに普及している。

本装置の最大の利点は、非破壊・非接触な測定が可能で あることと、長手方向の $I_{\mathrm{c}}$ 分布の評価速度は $\Delta x=1 \mathrm{~mm}$ の 空間分解能で $300 \mathrm{~m} / \mathrm{h}$ と高速に評価できる点にある。前節 で述ベたリール式四端子法に比べ空間分解能が高く、線材 内の局所的 $I_{\mathrm{c}}$ 低下の有無をスクリーニングする上では極め て有効な評価技術である。ただし、線材の幅方向に局所的 に $I_{\mathrm{c}}$ 変化がある場合や、線材の実効的な有効幅の評価を行 うには幅方向の空間分解能が十分でない。また、上述した $I_{\mathrm{c}}$ の最大值と最小值の差異が線材プロセスの何に起因して いるのかなど、不均一性の原因を把握するためには必ずし も十分な情報を得ることができない。

\section{3 リール式走査型 Hall 素子顕微鏡}

近年特に、HTS 応用機器や導体の可設計性や安定動 作実現のために長尺 HTS 素線の空間均一性の実現が 極めて重要な開発項目となっている。しかしながら、 テープ線材特有の問題として、2 次元的な超電導テー プ面内に点在する局所欠陥を、長尺に亘って高い空 間分解能で高感度に検出することは容易ではなく、 局所不均一性の発生メカニズムの解明はおろか、そ のための観測手法すら十分に確立されていないのが 現状である。実用レベルの長尺線に適用可能な、高 速かつ高感度 ・高分解能の評価手法の確立は、高温 超電導線材開発、実用化のために喫緊の課題となっ ている。

筆者らは、2.3 節に述べた SHPM の評価手法を高速化さ せ、リール式の線材搬送機構と組み合わせることによって、 連続的に着磁しながら長尺線の磁気像を取得する磁気顕微 鏡の開発を行った ${ }^{34,35)}$ 。走查機構の高速化と同時に、磁 界信号計測時の周波数帯域の増大によって SN 比の低下が 問題となるが、計測システムの低雑音化によってこの問題 をクリアし、短尺測定時の測定精度を保ったまま長尺線材 の高速評価を実現している。1 ch の Hall センサを用いた システムにおいて、長手方向の空間分解能 $1 \mathrm{~mm}$ 、幅方向 の空間分解能 $40 \mu \mathrm{m}$ の条件下で、ほぼ実用レベルの評価 速度 $36 \mathrm{~m} / \mathrm{h}$ を達成している ${ }^{34)}$ 。Fig. 12 にコート線材の評 価例を示す。局所 $J_{\mathrm{c}}$ 低下部位のサイズならびにテープ面 内の位置を明瞭に捉えていることが分かる。

本装置を用いて、既に数 $100 \mathrm{~m}$ 級線材の評価実績を多 く挙げており、長尺線材における $I_{\mathrm{c}}$ 分布の統計的振る舞 いに関する新たな知見を得ると共に、本装置で初めて可能 となった長尺線材の電磁気的有効幅の評価法の提出や、そ れを用いた線材加工技術の最適化など、本装置を用いて希 土類系コート線材の高性能化に関する有益な成果を挙げて いる ${ }^{11)}$ 。

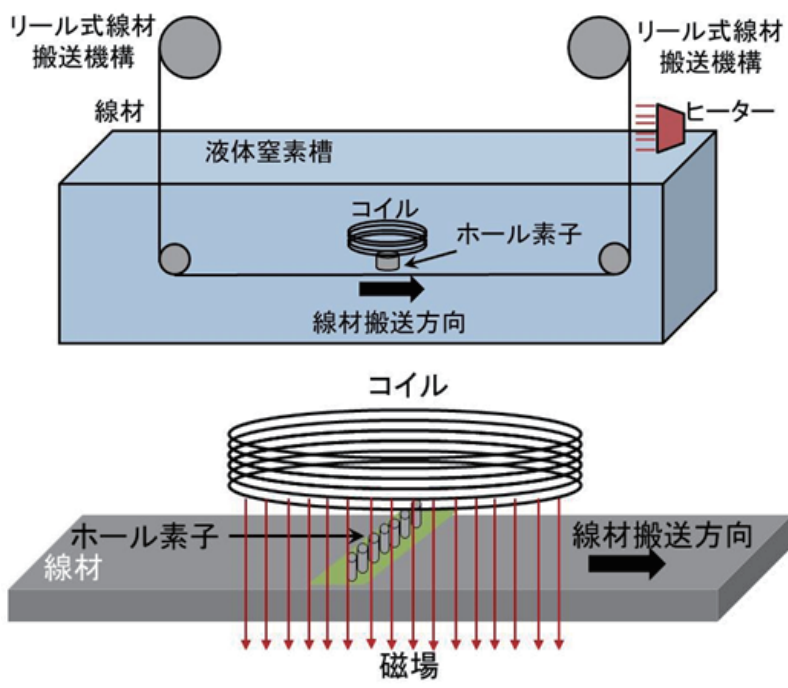

Fig. 10 Schematic diagram of the Hall sensor array measurement system well-known as Tapestar $^{\mathrm{TM}}{ }^{32}$ (upper), and its sensing area (lower).

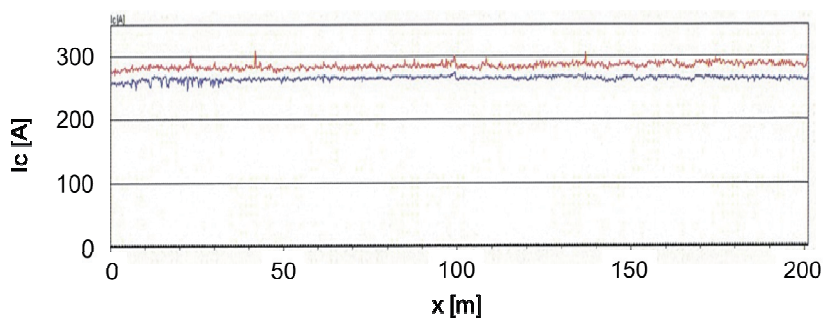

Fig. 11 An example of measurement results using Tapestar $^{\mathrm{TM}}$. The sample is a $200 \mathrm{~m}$-long commercially coated conductor. The red and blue lines are longitudinal variation of maximum- and minimum-value of $I_{\mathrm{c}}$ as a function of longitudinal coordinates, respectively.
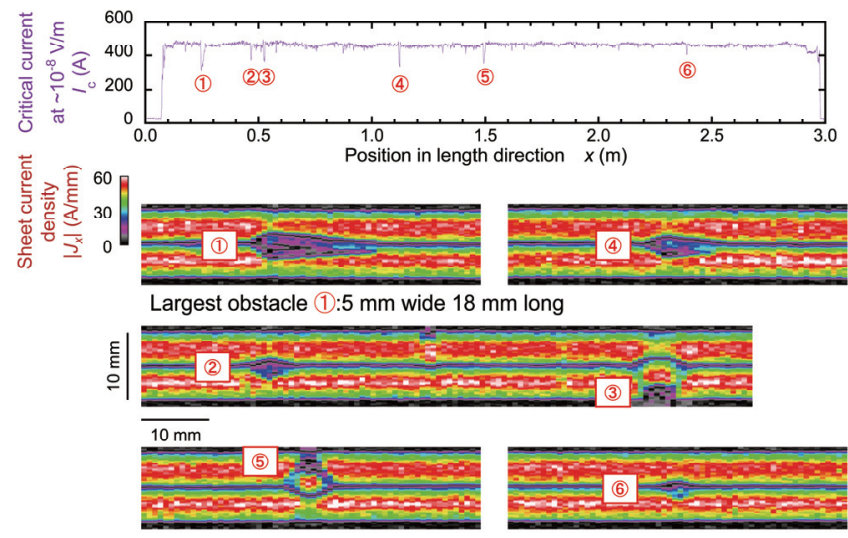

Fig. 12 Reel-to-reel SHPM visualizing local $J_{\mathrm{c}}$ drop in a $1 \mathrm{~cm}$ wide coated conductor.

\section{4 リール式磁気光学イメージング}

SHPM と同様に、テープ面内の 2 次元的 $J_{\mathrm{c}}$ 分布を長尺 に亘って評価することを目的に、町らは MOI 法をリール 式線材搬送機構と組み合わせた装置を開発している ${ }^{36)}$ 。 
インジケータフィルムには 1 インチの磁気光学膜を用い、 $16 \mathrm{~mm}$ 角の領域の像を一度に取得可能であり、解像度は 1 $\mu \mathrm{m}$ と SHPM に比べ高解像度な測定が可能である。ただし、 線材搬送機構は SHPM に比べると複雑になっており、線 材搬送中のインジケータフィルムの反射面の損傷を防ぐた め、観察時のみにインジケータフィルムを圧着し、線材搬 送中はインジケータフィルムを持ち上げた状態で $16 \mathrm{~mm}$ の区間ごとに線材を送り、偏光顕微鏡像を繰り返し取得す る。その結果、測定速度は今のところ $1.5 \mathrm{~m} / \mathrm{h}$ と SHPM に 比べるとかなり遅い。

Fig. 13 に本装置によるコート線材の観測例を示す ${ }^{36)}$ 。同 図の白い部分は磁界の高い領域で有り、局所的に $J_{\mathrm{c}}$ が低下 した磁界侵入領域を明瞭に捉えていることが分かる。同図 の下の像は Tapestar ${ }^{\mathrm{TM}}$ によって同一線材を観測した結果で ある。Tapestar ${ }^{\mathrm{TM}}$ の測定では、暗い領域が磁界が侵入して いる低 $J_{\mathrm{c}}$ の領域に対応する。Tapestar ${ }^{\mathrm{TM}}$ では欠陥部位の幅 方向の位置が不明瞭であるのに対し、リール式 MOI 装置 では、線材幅方向の構造が明瞭に捉えられており、面 内での欠陥位置の同定が可能である。すなわち、 $\operatorname{Tapestar}^{\mathrm{TM}}$ で捉えられた長手方向の $I_{\mathrm{c}}$ 低下の原因を解明 するにあたって、2 次元的な評価との複合化が有効で あることが分かる。

\section{4. まとめ}

\section{1 各種評価手法の特徵}

本稿で紹介した、代表的な $J_{\mathrm{c}}$ 分布評価手法について、 現状の典型的な性能と特徵をまとめた表を Table 1 に示す。 使用目的に応じて、必要となる空間分解能、評価速度、動 作環境は異なることから、一つの観測手法で全ての目的を カバーすることは難しい。適した評価手法を選択し、組み 合わせることによって複合的評価を行うことが最も有効で ある。

\section{2 今後の課題}

前項で述べたとおり、評価手法によって空間分解能、電 界基準など何桁も異なる。その結果、一口に $J_{\mathrm{c}}$ 分布と いっても見かけ上の $J_{\mathrm{c}}$ 分布や均一性は測定法によって大 きく異なっており、線材の均一性の定義そのものもまだ十 分に確立できていない。各評価手法によって得られる $J_{\mathrm{c}}$ 值ならびに $J_{\mathrm{c}}$ 分布の相互の関係を定量的に明らかにする と共に、線材性能の評価手法として標準化が今後必要に なってくると考えられる。一つのアプローチとして、筆者 らは SHPM による高解像度計測の結果をもとに、測定電 界ならびに空間分解能の校正を行うことによって、SHPM の結果と、四端子法の結果とが定量的に良く一致すること を示している。また、空間分解能による見かけ上の標準偏 差の変化は、空間周波数解析の結果から観測の際の空間周 波数帯域を考慮することによって定量的に説明できること を示している ${ }^{37,38)}$ 。このような長尺線材の $J_{\mathrm{c}}$ 摇らぎの振
$100 \mathrm{~mm}$

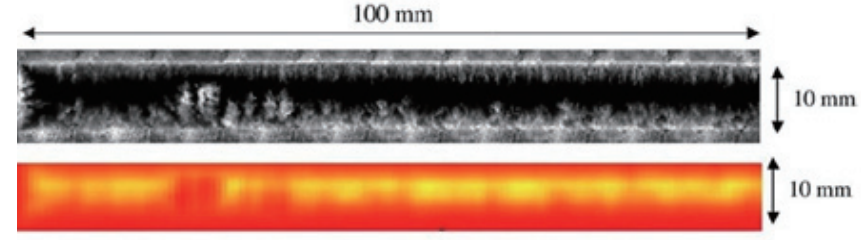

Fig. 13 Reel-to-reel MOI (upper) visualizing local flux penetration in a $1 \mathrm{~cm}$-wide coated conductor, and the results using Tapestar ${ }^{\mathrm{TM}}$ (lower) obtained for the same sample. ${ }^{36)}$

Table 1 Comparison among typical methods for spatially resolved measurement on local $J_{\mathrm{c}}$ in HTS tapes

\begin{tabular}{|c|c|c|c|c|c|c|c|}
\hline & 評価手法 & \begin{tabular}{|c|} 
長手方向 \\
分解能 \\
\end{tabular} & $\begin{array}{l}\text { 幅方向 } \\
\text { 分触能 }\end{array}$ & $\begin{array}{c}\text { 電界基準 } \\
(\mathrm{V} / \mathrm{m}) \\
\end{array}$ & 磁界筯团 & 温度範囲 & 測定速度 \\
\hline \multirow{4}{*}{ 短尺 } & LTLSM & $2 \sim 3 \mu \mathrm{m}$ & $2 \sim 3 \mu \mathrm{m}$ & $\sim 10^{-2}$ & e.f. 数 $\mathrm{T}$ & 0 & 0 \\
\hline & SSM & $2 \sim 3 \mu \mathrm{m}$ & $2 \sim 3 \mu \mathrm{m}$ & $\sim 10^{-8}$ & $\begin{array}{l}\text { <数 } 100 \\
\text { IT }^{\top}\end{array}$ & ○) & 0 \\
\hline & SHГM & $20 \sim 30 \mu \mathrm{m}$ & $20 \sim 30 \mu \mathrm{m}$ & $\sim 10^{-8}$ & s.f. $\sim$ 数 $\mathrm{T}$ & (-) & 0 \\
\hline & MOI & $-1 \mu \mathrm{m}$ & $-1 \mu \mathrm{m}$ & $\sim 10^{-8}$ & $\angle 0.1 \mathrm{~T}$ & ○) & ๑) \\
\hline \multirow{4}{*}{ 長尺 } & リール式四端子法 & $0.5 \sim 5 \mathrm{mI}$ & $x$ & $10^{-4}$ & $<1 T$ & $77 \mathrm{~K}$ & 0 \\
\hline & 配列Hall素子法 & $\sim 1 \mathrm{~mm}$ & $\Delta$ & $\sim 10^{-6}$ & 数10 mT & $77 \mathrm{~K}$ & (2) \\
\hline & リール式SHPM & $<1 \mathrm{~mm}$ & $20 \sim 30 \mu \mathrm{m}$ & $\sim 10^{-8}$ & 数 $10 \mathrm{mT}$ & $77 \mathrm{~K}$ & 0 \\
\hline & リールエ工іMOI & $\sim 1 \mu \mathrm{m}$ & $\sim 1 \mu \mathrm{m}$ & $\sim 10^{-8}$ & 数 $10 \mathrm{mT}$ & () & $\Delta$ \\
\hline
\end{tabular}

る舞いについて、観測結果をもとに理論的に考察し、その 機構を明らかとすることによって、各評価手法を定量的に 関係づけることが可能であると考えている。

本研究の一部は、超電導応用基盤技術研究開発ならびに 超軽量高性能モータ等向けイットリウム系複合材料の開発 の一環として、(公財) 国際超電導産業技術研究センター (ISTEC) を通じて、新エネルギー・産業技術総合開発機 構（NEDO）からの委託を受けると共に、日本学術振興会 の科研費 (15360151，18360153，20360143，24360122）の助 成を得て実施したものである。

\section{参 考 文 献}

1) E.H. Brandt and M. Indenbom: "Type-II-superconductor strip with current in a perpendicular magnetic field," Phys. Rev. B 48 (1993) 12893-12906.

2) K. Yamafuji and T. Kiss: "A new interpretation of the glass-liquid transition of pinned fluxoids in high- $T_{\mathrm{c}}$ superconductors," Physica C 258 (1996) 197-212.

3) T. Kiss, M. Inoue, S. Egashira, T. Kuga, M. Ishimaru, M. Takeo, T. Matsushita, Y. Iijima, K. Kakimoto, T. Saitoh, S. Awaji, K. Watanabe and Y. Shiohara: "Percolative transition and scaling of transport $E-J$ characteristics in YBCO coated IBAD tape," IEEE Trans. Appl. Supercond. 13 (2003) 2607-2610.

4) M. Friesen and A. Gurevich: "Nonlinear current flow in superconductors with restricted geometries," Phys. Rev. B 63 (2001) 64521-64547.

5) T. Kiss, M. Inoue, S. Egashira, M. Yasunaga, H. Tokutomi, M. Takeo, H.G. Shirinyan, S.G. Gevorgyan, Y. Iijima, K. Kakimoto 
and T. Saitoh: "Imaging of the local dissipation in YBCO coated tapes," Adv. Cryo. Eng.: Trans. ICMC (American Institute of Physics) 50 (2004) 677- 684.

6) T. Kiss, M. Inoue, M. Yasunaga, H. Tokutomi, Y. Iijima, K. Kakimoto, T. Saitoh, Y. Tokunaga, T. Izumi and Y. Shiohara: "Low temperature scanning laser microscopy of YBCO coated IBAD tapes," IEEE Trans. Appl. Supercond. 15 (2005) 3656-3659.

7) M. Inoue, T. Kiss, H. Tokutomi, T. Shoyama, K. Imamura, M. Takeo, Y. Iijima, K. Kakimoto, T. Saitoh, Y. Tokunaga, T. Izumi and Y. Shiohara: "Study on local inhomogeneity in TFA-MOD YBCO coated conductor by use of low temperature scanning laser microscopy," Physica C 426-431 (2005) 1073-1077.

8) T. Kiss, M. Inoue, T. Shoyama, S. Koyanagi, D. Mitsui, T. Nakamura, K. Imamura, A. Ibi, Y. Yamada, T. Kato, T. Hirayama and Y. Shiohara: "Visualizing transport properties in IBAD based YBCO coated conductors by multiple analysis techniques," IEEE Trans. Appl. Supercond. 17 (2007) 3211-3214.

9) K. Koyanagi, T. Kiss, M. Inoue, T. Nakamura, K. Imamura, M. Takeo and Y. Shiohara: "Measurement of local current flow around transverse defects in YBCO film by use of scanning SQUID microscope," Physica C 445-448 (2006) 677-681.

10) B.J. Roth, N.G. Sepulveda and J.P. Wikswo, Jr : "Using a magnetometer to image a two-dimensional current distribution," J. Appl. Phys. 65 (1989) 361-372.

11) K. Higashikawa, M. Inoue and T. Kiss: "Characterization of local $J_{\mathrm{c}}$ distribution in superconducting wires and tapes based on scanning Hall-probe microscopy," TEION KOGAKU 49 (2014) 485-493 (in Japanese)

東川甲平、井上昌睦、木須隆暢：「走査型ホール素子顕微鏡 による超伝導線材の局所 $J_{\mathrm{c}}$ 分布評価」、低温工学 49 (2014) 485-493

12) K. Higashikawa, M. Inoue, T. Kawaguchi, K. Shiohara, K. Imamura, T. Kiss, Y. Iijima, K. Kakimoto, T. Saitoh and T. Izumi: "Scanning Hall-probe microscopy system for two-dimensional imaging of critical current density in RE-123 coated conductors," Physica C 471 (2011) 1036-1040.

13) Y. Honda, K. Higashikawa, M. Inoue, T. Kiss, N. Ayai, M. Kikuchi, K. Hayashi and K. Sato: "Study on critical current distribution in CT-OP Bi-2223 tape based on the scanning Hall probe magnetic microscopy," Physica C 470 (2010) 1377-1379.

14) K. Furukawa, K. Higashikawa, K. Imado, M. Inoue, M. Kikuchi, S. Kobayashi, T. Nakashima, K. Hayashi, K. Sato, M. Tomita and T. Kiss: "Influence of self-field on critical current density distribution in Bi-2223 tape and current capacity in parallel conductor," IEEE Trans. Appl. Supercond. 25 (2015) submitted.

15) K. Higashikawa, Y. Honda, M. Inoue, M. Iwakuma, T. Kiss, K. Nakao, Y. Yamada and T. Izumi: "Spatially-resolved measurement on time-dependent electromagnetic behavior in alternating current carrying coated conductor," Physica C 470 (2010) 1280-1283.

16) A.A. Polyanskii, A. Gurevich, A.E. Pashitski, N.F. Heinig, R.D. Redwing, J.E. Nordman and D.C. Larbalestier: "Magneto-optical study of flux penetration and critical current densities in [001] tilt $\mathrm{YBa}_{2} \mathrm{Cu}_{3} \mathrm{O}_{7-\delta}$ thin-film bicrystals," Phys. Rev. B 53 (1996) $8687-$ 8697.

17) A.E. Pashitski, A. Gurevich, A.A. Polyanskii, D.C. Larbalestier, A. Goyal, E.D. Specht, D.M. Kroeger, J.A. DeLuca and J.E. Tkaczyk: "Reconstruction of current flow and imaging of current-limiting defects in polycrystalline superconducting films," Science $\mathbf{2 7 5}$ (1997) 367-369.

18) D.M. Feldmann, J.L. Reeves, A.A. Polyanskii, A. Goyal, R. Feenstra, D.F. Lee, M. Paranthaman, D.M. Kroeger, D.K. Christen, S.E. Babcock, D.C. Larbalestier: "Magneto-optical imaging of transport currents in $\mathrm{YBa}_{2} \mathrm{Cu}_{3} \mathrm{O}_{7-\mathrm{x}}$ on $\mathrm{RABiTS}^{\mathrm{TM}}$," IEEE Trans. Appl. Supercond. 11 (2001) 3772-3775.

19) T. Machi, J. Matsuda, N. Chikumoto, I. Hirabayashi, Y. Tokunaga, Y. Kitoh, Y. Aoki and T. Izumi: "MO observation on $\mathrm{YBa}_{2} \mathrm{Cu}_{3} \mathrm{O}_{7-\delta}$ coated conductors obtained by TFA-MOD technique," Physica C 426-431 (2005) 1078-1082.

20) J.H. Claassen, M.E. Reeves and R.J. Soulen Jr.: “A contactless method for measurement of the critical current density and critical temperature of superconducting films," Review of Scientific Instruments 62 (1991) 996-1004.

21) H. Yamasaki, Y. Mawatari and Y. Nakagawa: "Nondestructive determination of current-voltage characteristics of superconducting films by inductive critical current density measurements as a function of frequency," Appl. Phys. Lett. 82 (2003) 3275-3277.

22) K. Nakao, I. Hirabayashi and S. Tajima: "Application of an inductive technique to the characterization of superconducting thin films based on power law $I-V$ relations," Physica C 426-431 (2005) 1127-1131.

23) M. Eisterer, S. Haindl, T. Wojcik and H.W. Weber: “"Magnetoscan': a modified Hall probe scanning technique for the detection of inhomogeneities in bulk high temperature superconductors," Supercond. Sci. Technol. 16 (2003) 1282-1285.

24) M. Zehetmayer, R. Fuger, M. Eisterer, F. Hengstberger and H.W. Weber: "Assessment of the local supercurrent densities in long superconducting coated conductors," Appl. Phys. Lett. 90 (2007) 032506

25) S. Ohshima, K. Umezu, K. Hattori, H. Yamada, A. Saito, T. Takayama, A. Kamitani, H. Takano, T. Suzuki, M. Yokoo: "Detection of critical current distribution of YBCO-coated conductors using permanent magnet method," IEEE Trans. Appl. Supercond. 21 (2011) 2285-3388.

26) M. Igarashi, K. kakimoto, S. Hanyu, R. Kikutake, Y. Sutoh, R. Suzuki, M. Daibo, H. Fuji, H. Kutami, Y. Iijima, M. Itoh and T. Saitoh: "Advanced development of IBAD/PLD coated conductors at FUJIKURA,” Physics Procedia 36 (2012) 1412-1416.

27) V. Selvamanickam, Y. Chen, I. Kesgin, A. Guevara, T. Shi, Y. Yao, Y. Qiao, Y. Zhang, Y. Zhang, G. Majkic, G. Carota, A. Rar, Y. Xie, J. Dackow, B. Maiorov, L. Civale, V. Braccini, J. Jaroszynski, A. Xu, D. Larbalestier and R. Bhattacharya: "Progress in performance improvement and new research area for cost reduction of $2 \mathrm{G}$ HTS wires," IEEE Trans. Appl. Supercond. 21 (2011) 3049-3054.

28) M.W. Rupich, X. Li, S. Sathyamurthy, C.L.H. Thieme, K. DeMoranville, J. Gannon and S. Fleshler: "Second generation wire development at AMSC," IEEE Trans. Appl. Supercond. 23 (2013) 6601205.

29) J.Y. Coulter, T.G. Holesinger, J.A. Kennison, J.O. Willis and M.W. Rupich: "Nondestructive investigation of position dependent $I_{\mathrm{c}}$ variation in multi-meter coated conductors," IEEE Trans. Appl. Supercond. 19 (2009) 3609-3613.

30) J.O. Willis, Y. Coulter and M.W. Rupich: " $n$-value analysis of position-dependent property variability in long-length coated conductors," IEEE Trans. Appl. Supercond. 21 (2011) 2988-2991. 
31) J.J. Gannon, Jr., A.P. Malozemoff, R.C. Diehl, P. Antaya and A. Mori: "Effect of length scale on critical current measurement in high temperature superconductor wires," IEEE Trans. Appl. Supercond. 23 (2013) 8002005.

32) S. Furtner, R. Nemetschek, R. Semerad, G. Sigl and W. Prusseit: "Reel-to-reel critical cuyrrent measurement of coated conductors," Supercond. Sci. Technol. 17 (2004) S281-S284.

33) K. Nakao, T. Machi, S. Miyata, T. Muroga, A. Ibi, T. Watanabe, M. Konishi, Y. Yamada, Y. Kitoh, H. Fuji, Y. Aoki, T. Izumi and Y. Shiohara: "Non-destructive characterization of long coated conductors using a Hall sensor array," Physica C 445-448 (2006) 669-672.

34) K. Higashikawa, K. Shiohara, Y. Komaki, K. Okumura, K. Imamura, M. Inoue, T. Kiss, Y. Iijima, T. Saitoh, T. Machi, M. Yoshizumi, T. Izumi and H. Okamoto: "High-speed scanning Hallprobe microscopy for two-dimensional characterization of local critical current density in long-length coated conductor," Physics Procedia 27 (2012) 228-231

35) K. Higashikawa, K. Katahira, M. Inoue, T. Kiss, Y. Shingai, M. Konishi, K. Ohmatsu, T. Machi, M. Yoshizumi, T. Izumi, and Y. Shiohara: "Nondestructive diagnostics of narrow coated conductors for electric power applications," IEEE Trans. Appl. Supercond. 24 (2014) 6600704.

36) T. Machi, N. Chikumoto, K. Nakao, Y. Aoki, Y. Kitoh, H. Fuji, T. Izumi, A. Ibi and Y. Yamada: "Development of a magneto-optical imaging equipment for long length 2G-HTS tapes," Physica C 445-448 (2006) 673-676.
37) T. Kiss, K. Higashikawa, M. Inoue, K. Imamura, T. Taneda, A. Ibi, T. Yoshida, M. Yoshizumi, T. Izumi, Y. Shohara, K. Kimura, T. Koizumi, N. Aoki, T. Hasegawa, S. Awaji and K. Watanabe: "Spatial homogeneity and in-field current carrying capability of RE-123 coated conductors (invited)," presented at ICSM 2014, Antalya, Turkey, April 28, 2014.

38) T. Kiss, et al.: "Spatial frequency analysis on local critical current distribution in REBCO coated conductors," Abstract of 75th autumn meeting of the Japan Society of Applied Physics, 17pA21-8 (2014) 11-104.

木須隆暢ら：「REBCO 線材の局所臨界電流分布に対寸る空 間周波数解析」, 2014 年秋季第 75 回応用物理学会学術講演 会講演予稿集 17p-A21-8 (2014) 11-104.

木 須 隆 暢 1991 年九州大学大学院博士課程修了。1990 年日本学術振興会特別研究員、1991 年九州大学助手、1996 年同 助教授、2007 年同教授、現在に至る。超伝導システム科学研究 センター、低温センター併任。iSTERA 主管研究員。1999 年 Wisconsin 大学訪問研究員、2000 年 Twente 大学訪問研究員。この 間、超電導薄膜、SQUID、臨界電流特性に関する研究などに従 事。2006 年超伝導科学技術賞授賞。低温工学・超電導学会国際 交流委員会委員長、ICEC Board Member、ASC Board Member。低 温工学・超電導学会、応用物理学会、電気学会、電子情報通信学 会、MRS、IEEE、ACerS 各会員。工学博士。 